\title{
Levantamiento integrado para la documentación de arquitecturas históricas con influencia italiana en Colombia
}

\author{
Carla Ferreyra \\ Wendy Mejía Cabezas \\ Massimo Leserri
}

\section{Abstract}

En la actualidad, las nuevas tecnologías del levantamiento digital son cada vez más utilizadas como herramientas que responden exigencias sociales de recuperación de la memoria cultural, definida como la identidad de una sociedad en un determinado territorio.

Buscando dar respuesta a esta necesidad en un contexto latinoamericano, ha sido implementada una metodología de documentación y reconstrucción digital de un bien residencial de interés patrimonial en Colombia, la Casa de la familia Ferrari en Montería; una residencia significativa por su impronta europea en un contexto nativo tradicional. En esta investigación se desarrolla un procedimiento para el conocimiento avanzado del objeto de estudio y se experimentan técnicas de documentación, cada vez más eficaces. Con la intención de desvelar cada particular de la componente física dimensional del objeto arquitectónico, mediante datos gráficos e infográficos, se generan resultados a partir de los cuales es posible interpretar y representar la historia e imagen de su estado original. Los gráficos obtenidos, extraídos de modelos 3D, son elaborados y analizados en ambiente vectorial, según un procedimiento científico; donde el código grafico se convierte en un instrumento de representación y constituye la base para futuras intervenciones.

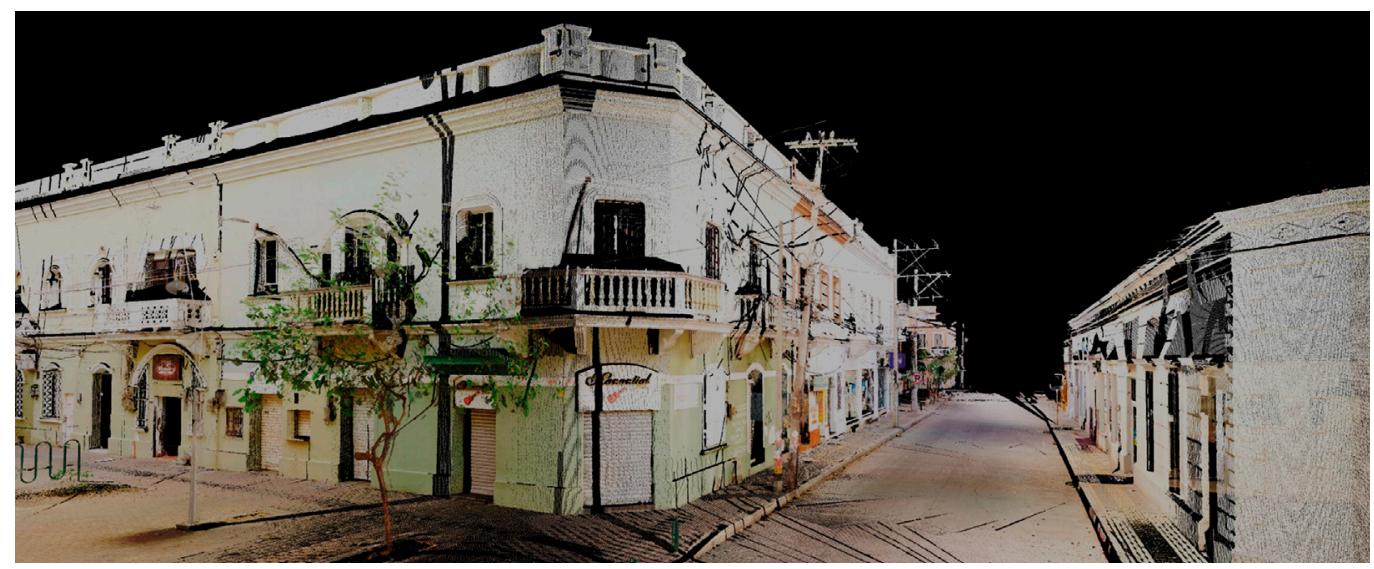




\section{Introducción}

El patrimonio cultural puede definirse como la identidad duradera de una ciudad y sus habitantes, es una disciplina en continua transformación que crea conciencia y fortalece el orgullo de los ciudadanos sobre su historia local [Hosagrahar 2016]. Los recursos culturales en las ciudades crean una sensación de pertenencia y un sentido de identidad entre las comunidades locales fomentando una fuerte promoción social, de inclusión y equidad. Además, fomentan el desarrollo sostenible de la ciudad, atraen turismo local, generan empleo y mejoran las condiciones de habitabilidad. De este modo, la promoción de los recursos culturales se convierte en un elemento clave para consolidar una ciudad inclusiva.

La puesta en valor del patrimonio arquitectónico es, de este modo, un deber para nuestras comunidades, un medio de preservación que permitirá perpetuar las tradiciones locales con el objetivo de transmitirlo a las generaciones futuras [Maggi $20 \mathrm{l} \mathrm{I].} \mathrm{Esta} \mathrm{investigación} \mathrm{su-}$ braya la estrecha relación existente entre documentación, interpretación y representación gráfica del patrimonio cultural y su preservación a lo largo del tiempo.

Buscando incentivar la sostenibilidad patrimonial; ha sido establecida una experiencia investigativa con carácter innovador, fundada en el levantamiento arquitectónico, como herramienta fundamental para realizar una intervención de conservación del bien patrimonial [Contell 2008].

El contexto de estudio de la investigación es la ciudad de Montería, conocida actualmente como la 'Perla del Sinú [Garcés González 1998], localizada al noroeste de la costa caribe colombiana (fig. I). Una ciudad con gran historia, legados arquitectónicos y costumbres arraigadas al rio Sinú; a orillas del rio, la avenida primera, ofrece un espacio para el intercambio cultural, y da lugar al parque lineal más grande de América Latina, un espacio que ha inspirado a poetas, pintores y artistas de la región [Exbrayat 197I]. Es necesario reconocer y preservar la identidad de la ciudad, cuyas características han sido modeladas por los ciudadanos que viven en ella.

Fig. I. Doble ilustración de la aplicación de la Ley de Indias, a la izquierda Fundación Santa Marta (I55I), a la derecha la Villa de San Carlos (1763). El Caribe Colombiano, 2017.
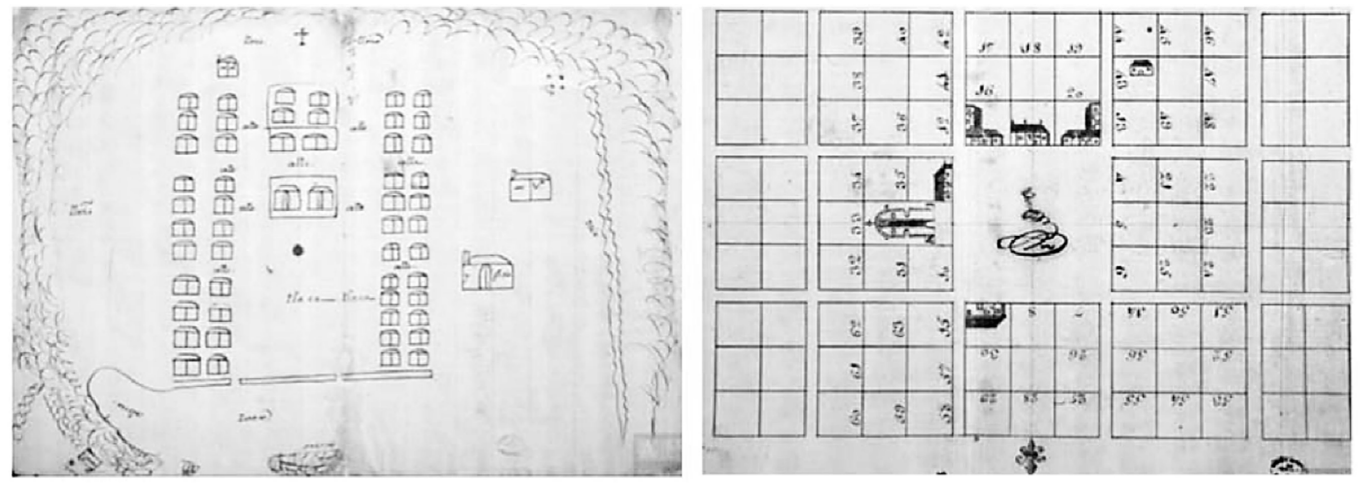

La ciudad adquiere mayor trascendencia recién a mediados de siglo $X X$ con un crecimiento notorio de la ciudad fruto de su posición geográfica estratégica que favoreció el comercio, y de este modo, la inmigración [Castro 2003]. Esta influencia comercial se verificó no solo en el intercambio de mercancía, sino incluso en los ideales artístico-arquitectónico; ejemplo de ello, esta Casa "italiana", valorada principalmente por su estilo e historia que rodea su construcción, que actualmente es motivo de investigación y preservación.

La Casa de los Ferrari es, probablemente, un caso más único que raro de Arquitectura estilo Liberty en Montería y tal vez en el Caribe Colombiano [Bell Lemus 20 I 7]. Esta arquitectura histórica es un elemento patrimonial importante en la memoria cultural de la ciudad. Debido a la carencia de información bibliográfica o documentación gráfica del objeto de estudio. Ha sido necesario recurrir a la única tipología de documentación disponible, fotográficas antiguas características. 
El objeto de estudio, significativo por su impronta europea en un contexto nativo tradicional, se encuentra identificado dentro de los "bienes culturales y arquitectónicos de la ciudad" [PEMP 2019] y reconocida como estilo Liberty [Leserri 2018], un Art Nouveau con influencia italiana, que ha despertado un gran interés en la sociedad por la pureza de su construcción y la particularidad del intercambio cultural-arquitectónico. Sin embargo, la Casa aún no está valorada dentro del patrimonio de la ciudad y por lo tanto no existe un estudio específico del mismo, no se encuentra documentación tangible que permita estudiar de manera directa el origen y la evolución que ha sufrido la vivienda desde el momento de su construcción en el año 1935.

La escasa documentación que se puede recuperar proviene de la tradición oral de algunos historiadores de la ciudad, se encuentran archivos fotográficos (fig. 2), libros sobre la historia la ciudad de Montería [Castro 2003], que definen la situación de aquella época en relación con el comercio, transporte, economía y justificación social de la llegada de extranjeros a la ciudad.

A partir de una investigación documentaria sujeta a elementos obtenidos mediante tradición oral y análisis de antiguos documentos, fotografías y diseños, se han rescatado las preexistencias de la composición original de la fachada, es posible verificar el mantenimiento en el tiempo de la mayor parte de los elementos constitutivos de la fachada. Ha sido realizado un levantamiento con el objetivo de explorar las particularidades de la arquitectura, liberándola de las transformaciones contemporáneas, buscando obtener la imagen de la casa en su estado original.

La primera etapa de la investigación consiste en realizar un recorrido analítico y visual sobre la arquitectura, historia y estilo a través de una recopilación de antiguas imágenes de la ciudad. El estudio se ha concentrado en la fachada, siendo el único elemento accesible para el análisis.

Fig. 2. Imágenes de la Casa "italiana" desde la Avenida primera en los años 30's. Autor desconocido digitalizadas por ocido, digitalizadas por Biblioteca Luis Ange Arango.
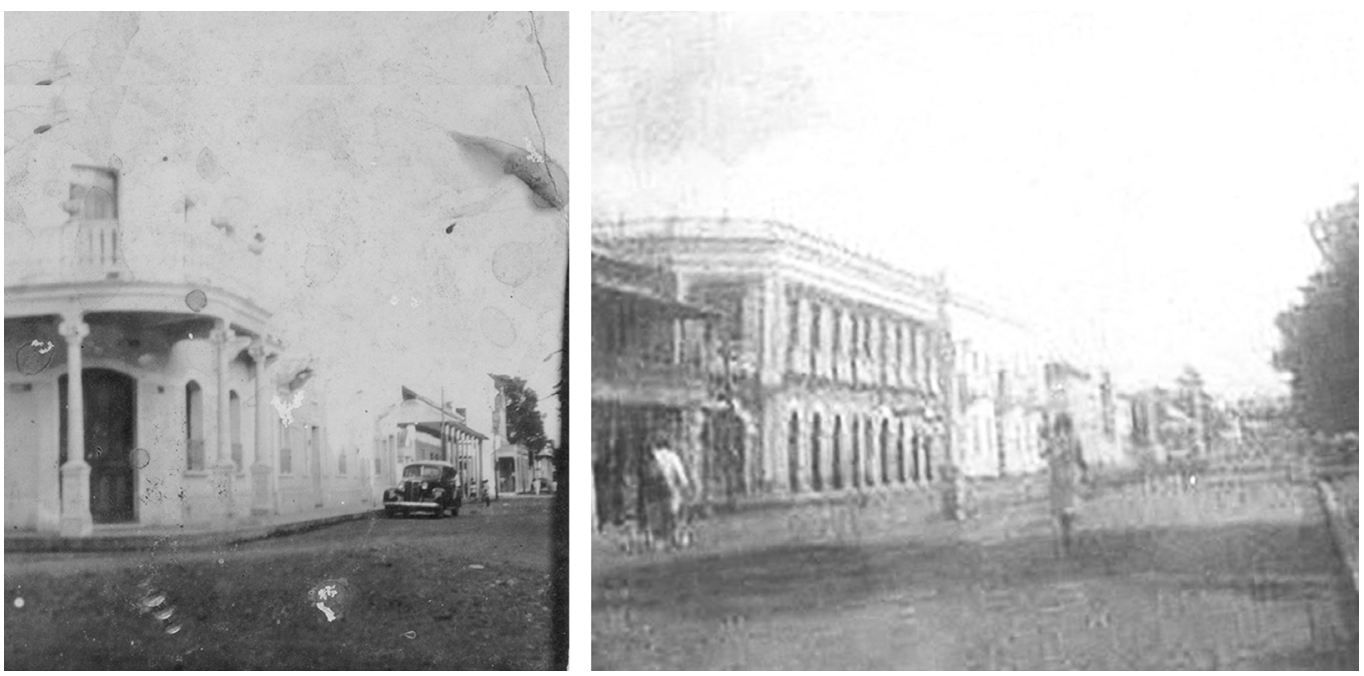

\section{Método}

Aunque los recursos tradicionales para la documentación del patrimonio, como la fotografía - el dibujo a mano alzada, sean continuamente utilizados por su accesibilidad y bajo costo, en la actualidad son cada vez más necesarias las tecnologías digitales, que evidencian un aumento en la cantidad y la calidad de los datos capturados (fig. 3).

Estas nuevas oportunidades digitales permiten al investigador experimentar diferentes métodos para comunicar la información a través de redes sociales y dispositivos multimedia, consiguiendo de este modo un mayor y mejor alcance al usuario, adquiriendo un mayor impacto social. 
Fig. 3. Esquema del procedimiento metodológico del presente proyecto.

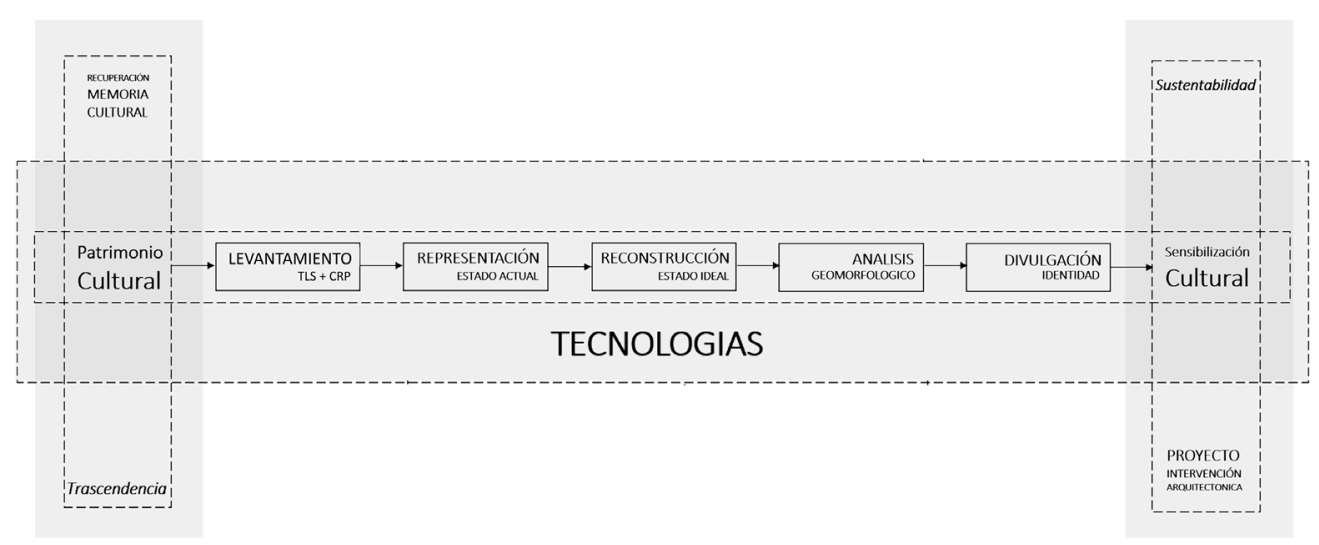

Los datos son capturados y procesados con el propósito de crear una documentación para su conocimiento y gestión. Mediante la integración de la información en complejos modelos 3D, implementados mediante plataformas interoperables, se convierte en una herramienta de análisis en el proceso de gestión y monitoreo, y por lo tanto de conservación del bien patrimonial.

En el campo digital de la representación gráfica el objetivo es rescatar todos los valores característicos del objeto de estudio como geometría, dimensión, material, entre otros; para luego interpretarlos, mediante la documentación obtenida y analizar las posibles transformaciones de la arquitectura con el paso del tiempo [Florio 20।4].

A partir de un enfoque multidisciplinar con la contribución de diferentes sectores cuales historia de la arquitectura, ingeniería gráfica y restauración arquitectónica, en ocasión de un proyecto de investigación iniciado con la base de un interesante trabajo de tesis de Wendy Mejía Cabezas del 2019, fue posible diseñar una metodología optimizada para lograr los objetivos requeridos, documentar y monitorear el estado del arte de objetos histórico-arquitectónicos, como base para una interpretación científica del mismo.

La primera fase de la investigación ha involucrado la recopilación de datos y un análisis significativo iconográfico y fotográfico del objeto de estudio. Como fase sucesiva fueron realizadas tres campañas de adquisición de datos, utilizando técnicas de levantamiento arquitectónico tradicionales y digitales.

Cada objeto de estudio, monumento, edificio, o elemento decorativo, tiene características únicas y se encuentra en condiciones particulares. Es necesario definir las técnicas utilizadas para cada proyecto, basándose en estas singularidades [Docci 2003]. Han sido utilizados técnicas de levantamiento digital con sensor activo (TLS) y pasivo (CRP).

TLS - Terrestrial Laser Scanning

Ha sido utilizado un escáner laser FARO M70 del Politécnico de Bari, utilizado en interiores y exteriores en aplicaciones que requieren escaneos de hasta 70 metros y una precisión de +/- I mm. Con una velocidad de adquisición de casi I.000.000 de puntos por segundo. La campaña de adquisición, realizada por el arq. Gabriele Rossi, ha previsto cinco estaciones para garantizar una correcta captura del objeto de estudio (fig. 4).

Durante la campaña se han tenido imprevistos como la circulación constante de personas y vehículos que afectaron la adquisición de la información de manera global. Con los datos proporcionados por el escáner (.fls) ha sido elaborada una nube de puntos de | | 9.86 |.68 | puntos al interno del software propietario Scene 2019.2.

CRP - Close Range Photogrammetry

Han sido recolectados con una Nikon D3500 24,2MP kit I8-55mm, caracterizada por producir imágenes (.tiff) de alta calidad, color e iluminación, un total de 125 fotografías (fig. 4), válidas solo 99 fotografías suprimiendo aquellas que se encontraban desenfocadas, repetidas y con información alterada por diversos elementos del ambiente exterior. Han sido utilizadas para elaborar un modelo 3D texturizado a base de nube de puntos al interno del software Agisoft Metashape 1.5. I. Algunos pasos fueron creación de la nube de puntos 
densa con 33.791.767 puntos, superficie poligonal con 2.252.783 triángulos, aplicación de la textura 4.096 pixeles. Para obtener datos geoespaciales precisos, fue realizada una correspondencia con los datos georreferenciados adquiridos con TLS.

Terrestrial Laser Scanning + Close Range Photogrammetry

Utilizando los datos adquiridos mediante escáner laser y fotogrametría en un mismo sistema de referencia, la nube de puntos TLS fue importada en Agisoft y fue generada una malla poligonal de 7.696.809 triángulos. Fue proyectada la textura con la información de las fotos, obteniendo de este modo, un resultado integrado y de mayor definición. Han sido construidas las ortofotos, una de cada fachada, con resolución de $10.655 \times 3.919$ pixeles, que han sido exportadas para su posterior vectorización en ambiente CAD. Por un lado, del estado actual de las fachadas, obteniendo una representación gráfica con un alto grado de detalle; y, por otro lado, ha sido realizada la vectorización de estado ideal de las fachadas, utilizando la base científica de la ortofoto e interpretando la información con la documentación recopilada en precedencia. Fue posible obtener una visualización con información referida al material, color y geometría, para documentar y comunicar la información histórica de la casa y construir la memoria cultural.

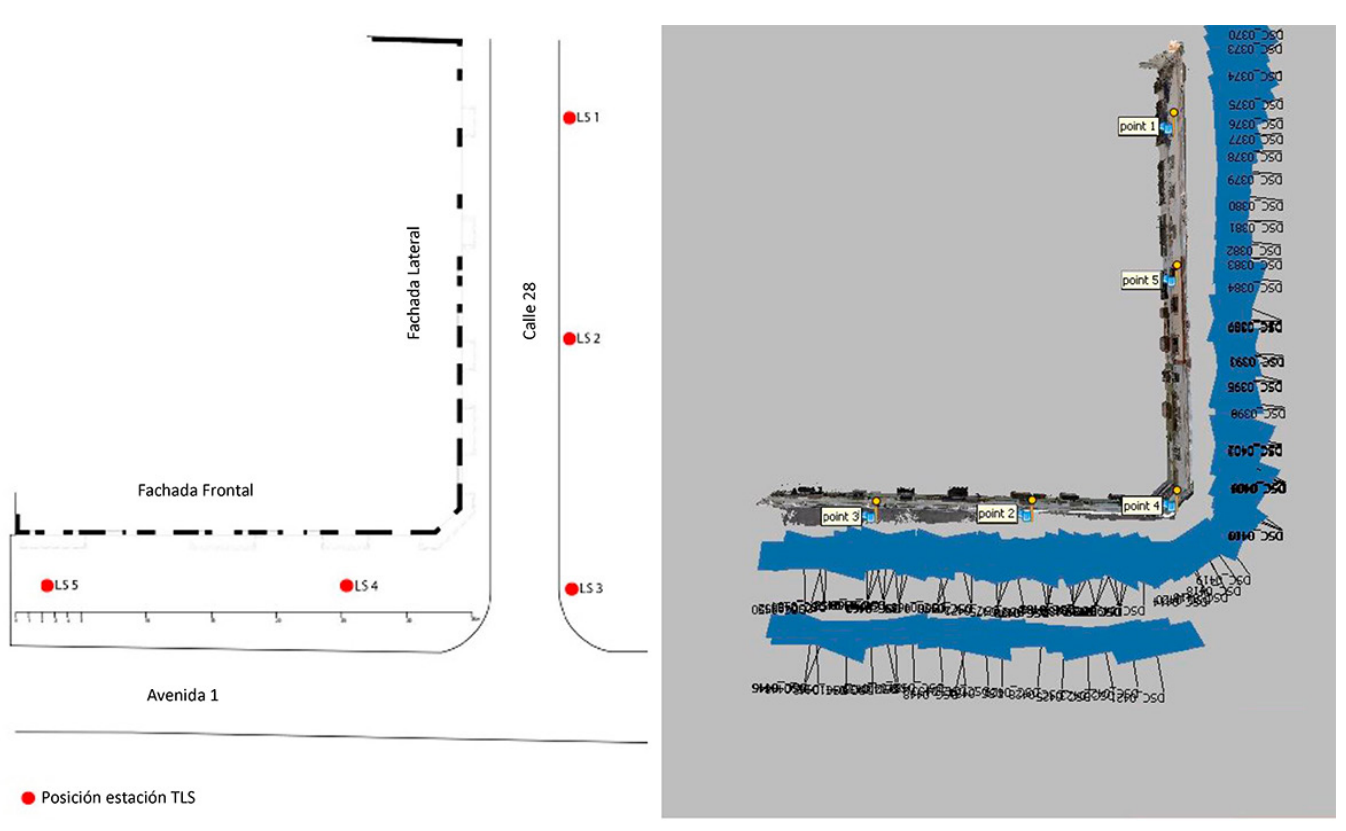

\section{Resultados}

Obteniendo como resultados, piezas técnicas a una escala arquitectónica adecuada para intervención de la fachada de la Casa Ferrari y cada uno de sus elementos. La última fase ha visto el análisis geomorfológico de la fachada y la construcción de un modelo tridimensional del estado actual e ideal cargado de componentes históricos que servirá como base para futuras, y eventuales, intervenciones [Piquer Cases 2015]. La potencialidad de un modelo tridimensional (fig. 5) se verifica en términos de análisis e interpretación, basados no solo en los datos digitales levantados, sino en precedentes estudios, observaciones y comparaciones; enfoque es válido para la reconstrucción científica.

Ha sido posible obtener una visualización con información referida al material, color y geometría, para el desarrollo futuro del modelado 3D. Para el modelado fue utilizado un software intuitivo y flexible, donde fueron importadas las piezas gráficas vectorizadas en CAD. 


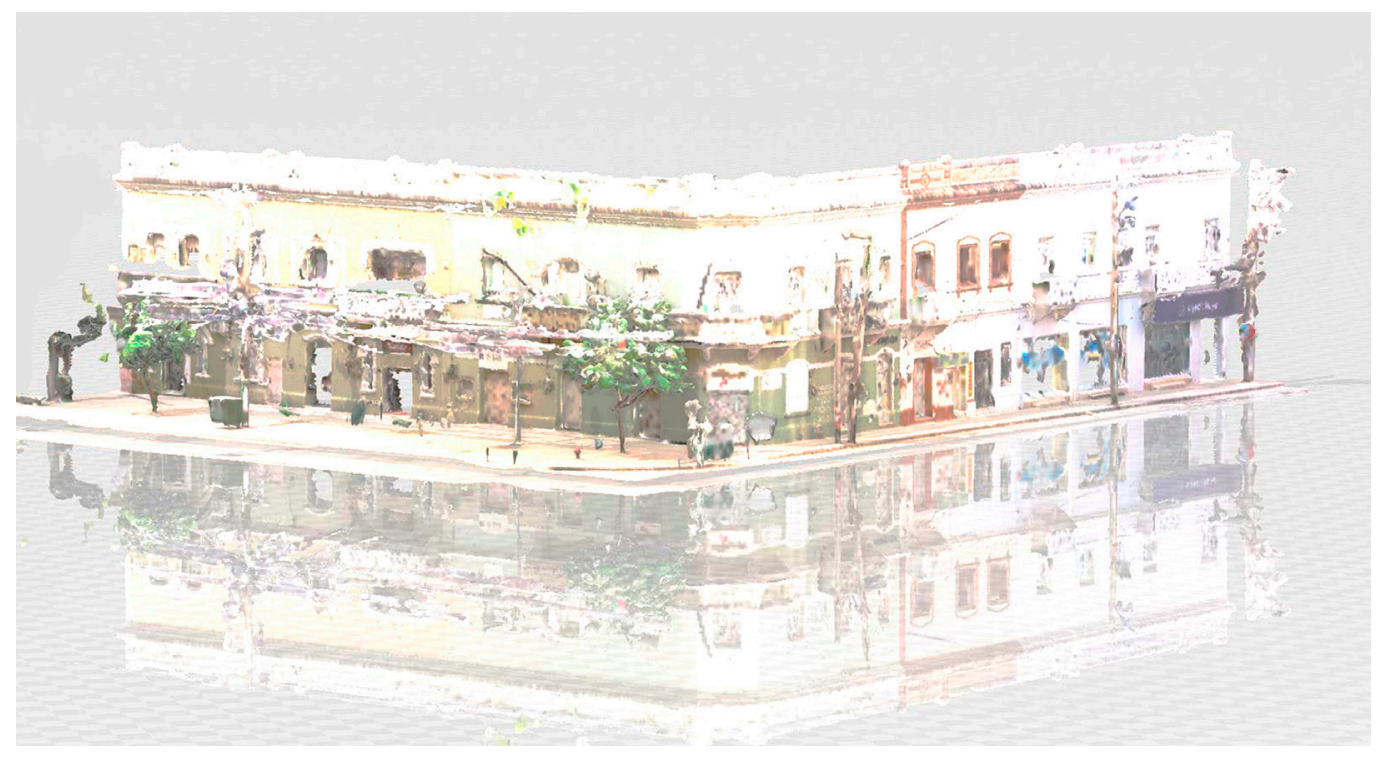

La superficie poligonal ayudó a verificar el perímetro de las paredes externas, las alturas de los elementos de detalle, como la posición correcta de las puertas, ventanas y todos los elementos externos.

Las oportunidades que ofrece la integración de técnicas digitales modernas, como la fotogrametría con los sistemas activos de escáner láser, permiten obtener nuevos productos mejorando la precisión del dato métrico [Barba 2019$]$. Esta integración permite reconstruir virtualmente sitios de interés artístico para documentar fielmente la realidad. Al mismo tiempo, proporciona una herramienta para interpretar la dinámica de la transformación de los objetos arquitectónicos como estrategia de visualización.

En particular, el objeto de estudio es un edificio con antecedentes históricos no solo a razón del contexto en el que es construido, sino por pertenecer a un estilo arquitectónico no arraigado a las construcciones de aquella época, con una fuerte influencia italiana, proyectada por ingenieros italianos, construida por constructores italianos para una familia italiana. Desde el levantamiento, se ha obtenido material gráfico que, combinado con la investigación realizada, documentos gráficos, escritos y analizando el contexto inmediato, se ha podido implementar una reconstrucción hipotética del estado original del objeto de estudio (figg. 6, 7), con la intención de contribuir a la concientización social sobre la importancia de la puesta en valor del patrimonio, no solo en Montería, sino con posibilidad de aplicarse en diferentes contextos.

\section{Conclusiones}

Son documentadas gráficamente las fachadas de la Casa de los Ferrari, elaboradas por primera vez con rigor científico y acompañadas de una profunda investigación documentaria que posibilita establecer una reconstrucción grafica de su estado original. Se reveló la importancia arquitectónica del caso de estudio, como memoria cultural de la ciudad de Montería, y se desvelaron las alteraciones, estilísticas y formales de las fachadas. A partir de estos primeros resultados se advierte incrementado el interés social por la búsqueda de antecedentes históricos del objeto de estudio y de su contexto. Por lo tanto, la representación gráfica del patrimonio se convierte en un primer paso hacia su puesta en valor y siendo un fiel reflejo de la identidad cultural y de la memoria histórica de un territorio habitado. La metodología, basada en levantamientos multisensoriales, documentos iconográficos, des- 


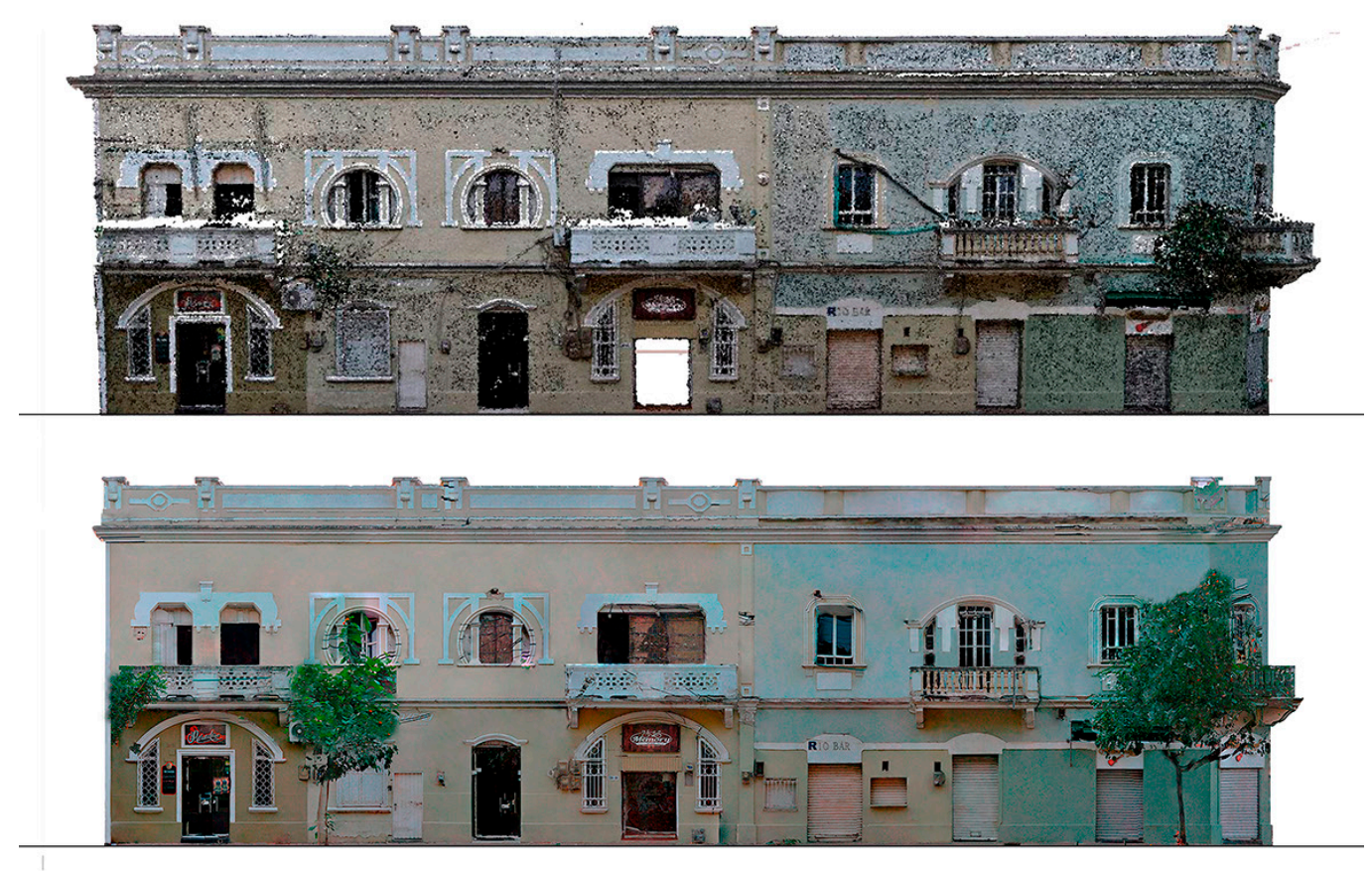

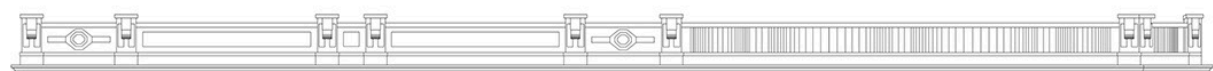

Fig. 6. Fachada Frontal: nube de puntos (TL-

S+CRP), ortofoto geolocalizada, vectorización de estado actual e ideal.

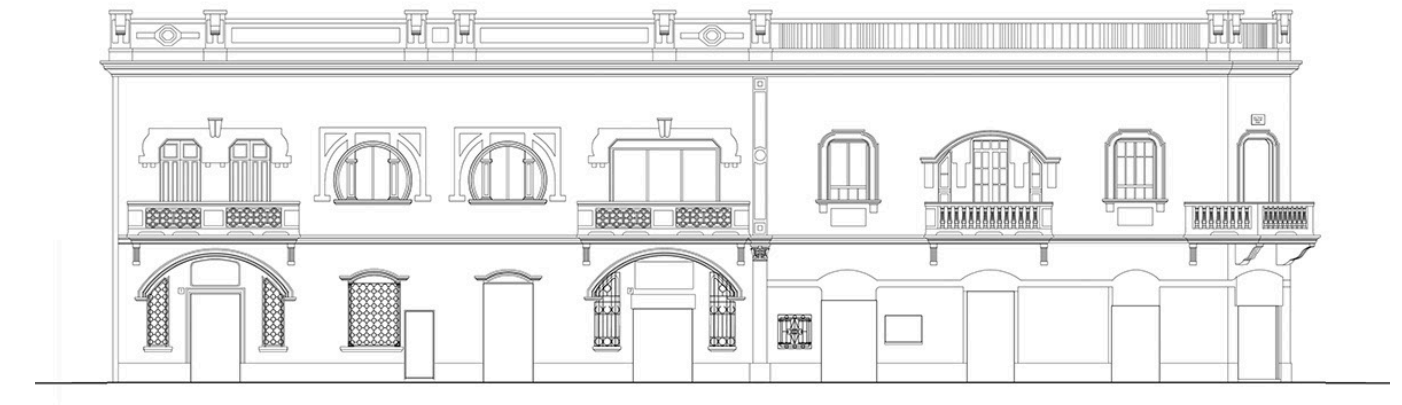

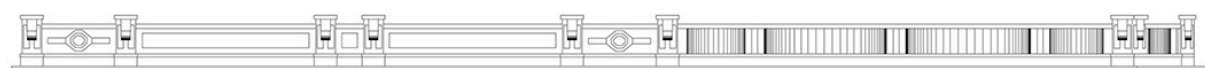

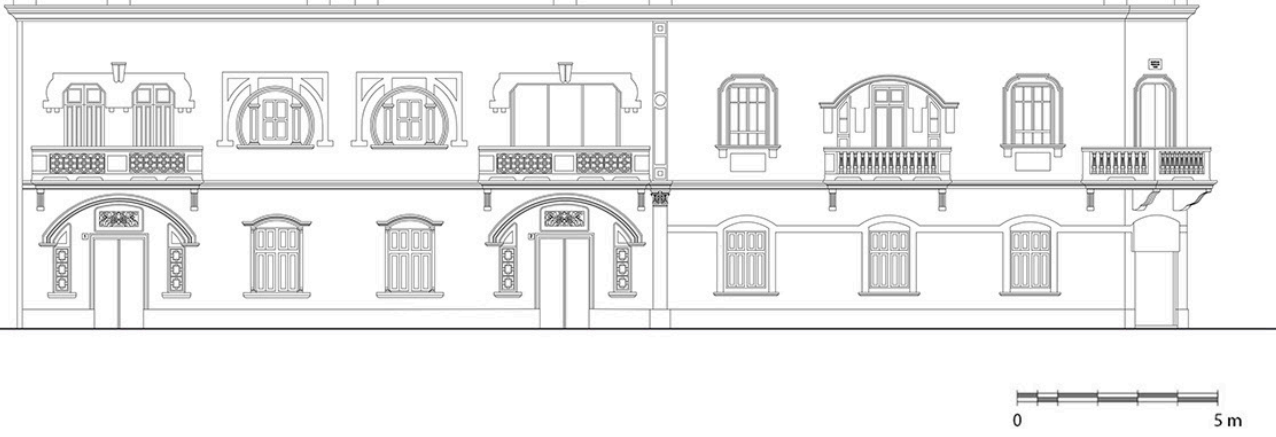



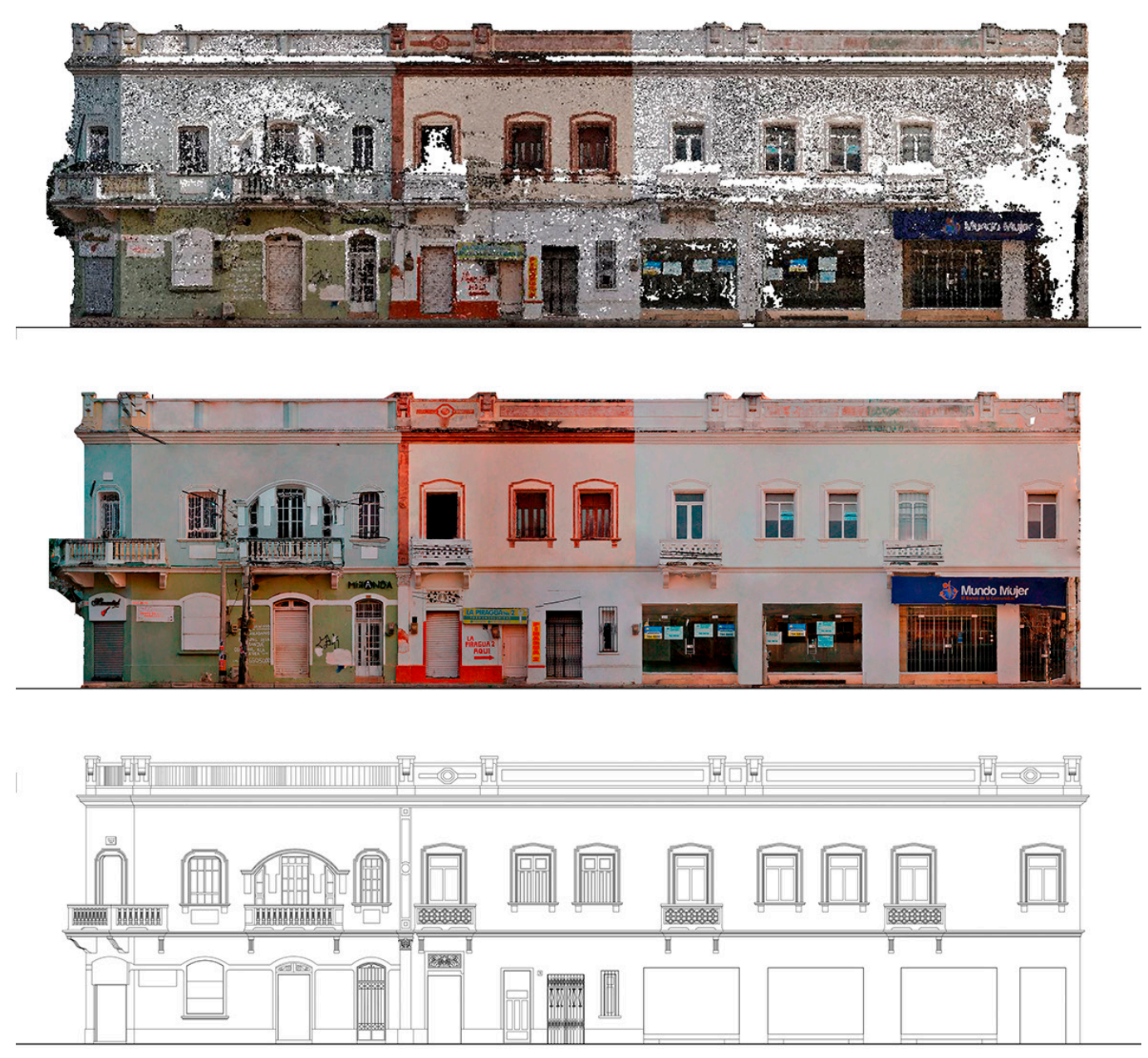

Fig. 7. Fachada Lateral:

nube de puntos (TL-

S+CRP), ortofoto geolocalizada, vectorización
estado actual e ideal.

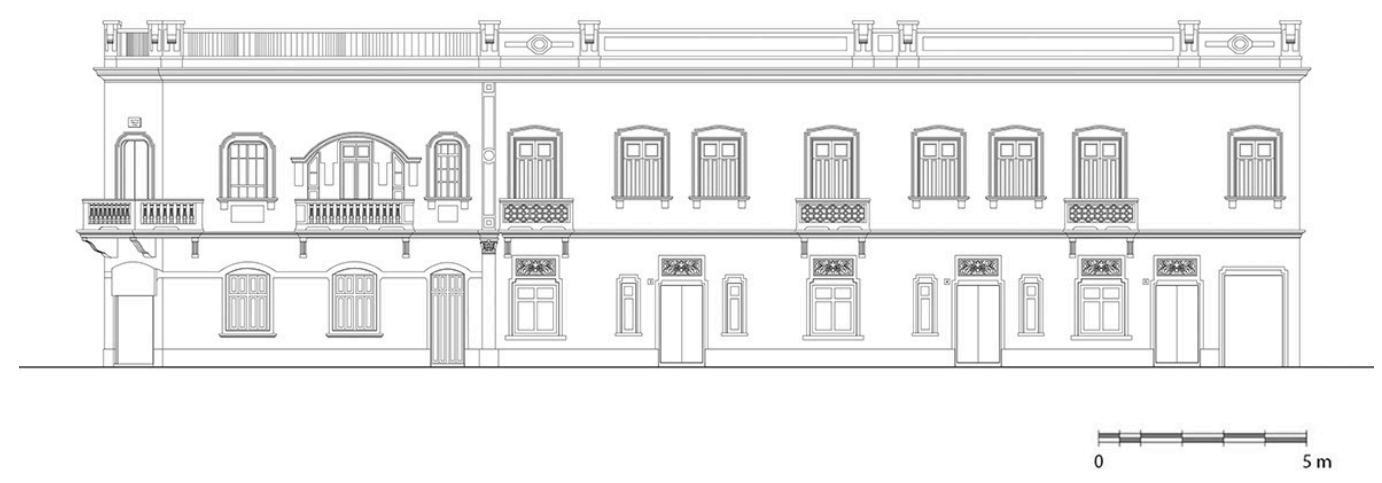


cripciones y antecedentes históricos, ha posibilitado la creación de un modelo virtual del cual es posible recabar información del objeto arquitectónico que, contextualizado, dará lugar a la construcción de la memoria urbana [Rossi 2003].

La reconstrucción virtual de un edificio no solo ayuda a la comprensión de su totalidad, sino que crea conciencia sobre la dimensión del patrimonio y se convierte en una poderosa herramienta de divulgación, eficaz incluso para un público vasto hacia una promoción cultural [Barba 2012].

La inédita documentación obtenida en este proyecto será una base científica para desarrollar proyectos de eventual renovación o restauración del edificio, garantizando un ahorro de tiempo y una precisa vista previa de la representación final (fig. 8). El interés cultural que se está desarrollando en la ciudad de Montería respecto a los bienes patrimoniales necesitan un fortalecimiento del debate cultural para crecer siempre más la atención político-cultural por parte de los administradores públicos y privados.

Como desarrollos futuros, se continuará investigando y recopilando información de estos bienes patrimoniales. La Academia y la investigación aportan un interés especifico hacia la comprensión del patrimonio cultural con la esperanza de desarrollar un crecimiento también formativo hacia la cultura de la restauración.

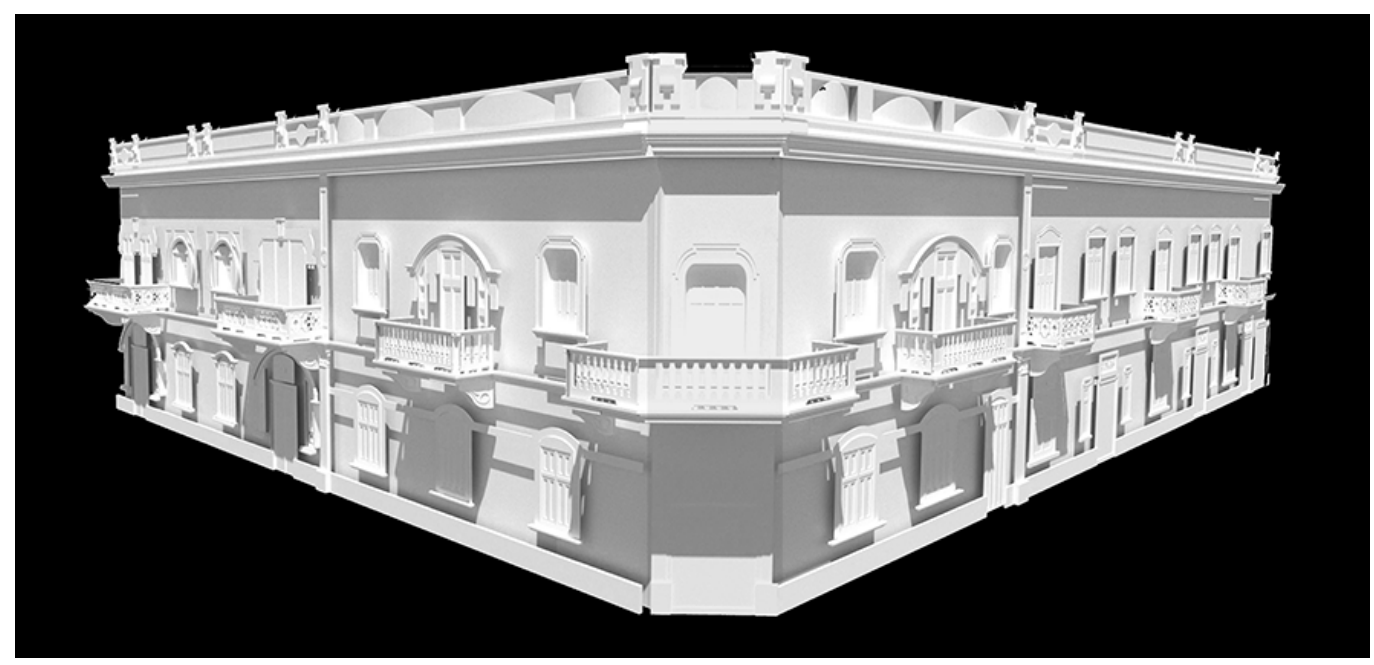

\section{Referencias}

Barba Salvatore, De Feo Emanuela, D'Auria Saverio, Guerriero Luigi (20 I2). Survey and virtual restoration:The Castle of Magacela, Spain. I 8th International Conference on Virtual Systems and Multimedia, Milan: IEEE, pp. 64 I-644.

Barba Salvatore, Barba Salvatore, di Filippo Andrea, Limongiello Marco, Messina Barbara (2019). Integration of active sensors for geometric analysis of the chapel of the Holy Shroud. In ISPRS - International Archives of the Photogrammetry, Remote Sensing and Spatial Information Sciences, Vol. XLII-2MI5.

Bell Lemus Carlos (20 I7). El Caribe Colombiano, Guía de Arquitectura y Pasaje. Sevilla: Barranquilla, pp. I7l.

Castro Jaime (2003). Historia extensa de Montería. Montería: Editorial ediciones Paloma.

Contell Marina (2008). El Monasterio De La Murta. El Levantamiento Arquitectónico como fase preliminar de estudio. In Revista de EGA, 13, pp. |28-I33.

Docci Mario, Maestri Diego (2003). Manuale di rilevamento architettonico e urbano. Editorial Laterza. Roma-Bari.

Exbrayat Jaime (197|). Historia de Montería. Montería, Colombia: Domus Libri.

Florio Riccardo, Della Corte Teresa, Frajese D'Amato Carmela (20/4). Materia e forma dell'architettura dimenticata. ॥ patrimonio rupestre dell'area metropolitana di Napoli: il caso dell'Eremo di S. Maria di Pietraspaccata Mara. In Giandebiaggi Paolo (a cura di). Survey \& International Experience. atti del $36^{\circ}$ Convegno Internazionale dei Docenti della Rappresentazione. Parma I 8-20 settembre 20 |4. Roma: Gangemi Editore, pp. 297-305.

Garcés González José Luis (1998). Crónicas para intentar una historia. Montería, Colombia: Crónicas. 
Hosagrahar Jyoti, Duxbury Nancy, Pascual Jordi (2016). Why must culture be at the heart of sustainable urban development? Agenda 21 for culture - Committee on culture of United Cities and Local Governments.

Leserri Massimo, Guerrero Hernandez Maria (20I8). El Levantamiento como instrumento para el conocimiento del patrimonio arquitectónico. El caso estudio de la Ronda del Sinú de Montería. Campos, Umbrales y Poéticas del Dibujo. VII Congreso Internacional y XV Congreso Nacional de Profesores de Expresión gráfica en Ingeniería, Arquitectura y carreras afines. La Plata, Argentina.

Maggi Diana (20l I ). Patrimonio arquitectónico y urbano. Universidad Nacional de la Plata, Facultad de arquitectura y urbanismo. La Plata, Argentina: Unirio Editora.

Plan Especial de Manejo y Protección (PEMP) (2019). Centro Histórico de la ciudad de Montería, Colombia.

Piquer Cases Juan Carlos, Capilla Tamborero Esther, Molina-Siles Pedro (2015). La Reconstrucción Virtual del patrimonio arquitectónico y su aplicación metodológica. In Revista de EGA, 25, pp. 258-267.

Rossi Gabriele (2003). Piazza dei Mercadanti a Lecce, Indagini grafico-visuali sulle trasformazioni urbanistiche di Piazza Sant' Oronzo. Lecce: Edizioni Del Grifo.

\section{Autores}

Carla Ferreyra, Universidad de Salerno, cferreyra@unisa.it

Wendy Mejía Cabezas, Universidad Pontificia Bolivariana de Montería,wendy.mejiac@upb.edu.co.

Massimo Leserri, Universidad de Salerno, mleserri@unisa.it

Para citar este capítulo: Ferreyra Carla, Mejìa Cabezas Wendy, Leserri Massimo (2020). Levantamiento integrado para la documentación de arquitecturas históricas con influencia italiana en Colombia/Integrated surveying techniques for the documentation of historical architectures with Italian influence in Colombia. In Arena A., Arena M., Brandolino R.G., Colistra D., Ginex G., Mediati D., Nucifora S., Raffa P. (a cura di). Connettere. Un disegno per annodare e tessere. Atti del $42^{\circ}$ Convegno Internazionale dei Docenti delle Discipline della Rappresentazione/Connecting. Drawing for weaving relationships. Proceedings of the 42th International Conference of Representation Disciplines Teachers. Milano: FrancoAngeli, pp. 2162-2 I8I. 


\title{
Integrated Surveying Techniques for the Documentation of Historical Architectures with Italian Influence in Colombia
}

\author{
Carla Ferreyra \\ Wendy Mejía Cabezas \\ Massimo Leserri
}

\section{Abstract}

Nowadays, the use of new technologies for digital survey is constantly increasing due to the social demands for the recovery of the cultural memory, in terms of the identity of a society in a particular territory. In order to respond to this need in a Latin American context, it was implemented a methodology to document and digitally reconstruct a residential property of patrimonial interest in Colombia, the House of the Ferrari's family in Montería, an important residence with European imprint in a traditional native context. In this research, it was developed a procedure to acquire an extensive knowledge of the object of study, while also experimenting innovative documentation techniques, which have proved to be increasingly effective. The idea of disclosing every detail of the physical aspects of the architectural object, was pursued through graphic and infographic data; the processing of these data finally resulted in an interpretation of the history, while also allowing to recreate an image of the original state of the building. The graphics obtained, directly extracted from the 3D models, were elaborated and analyzed in a vector environment, according to a scientific procedure; in this way the graphic code itself becomes a representation instrument and the very basis for future interventions.

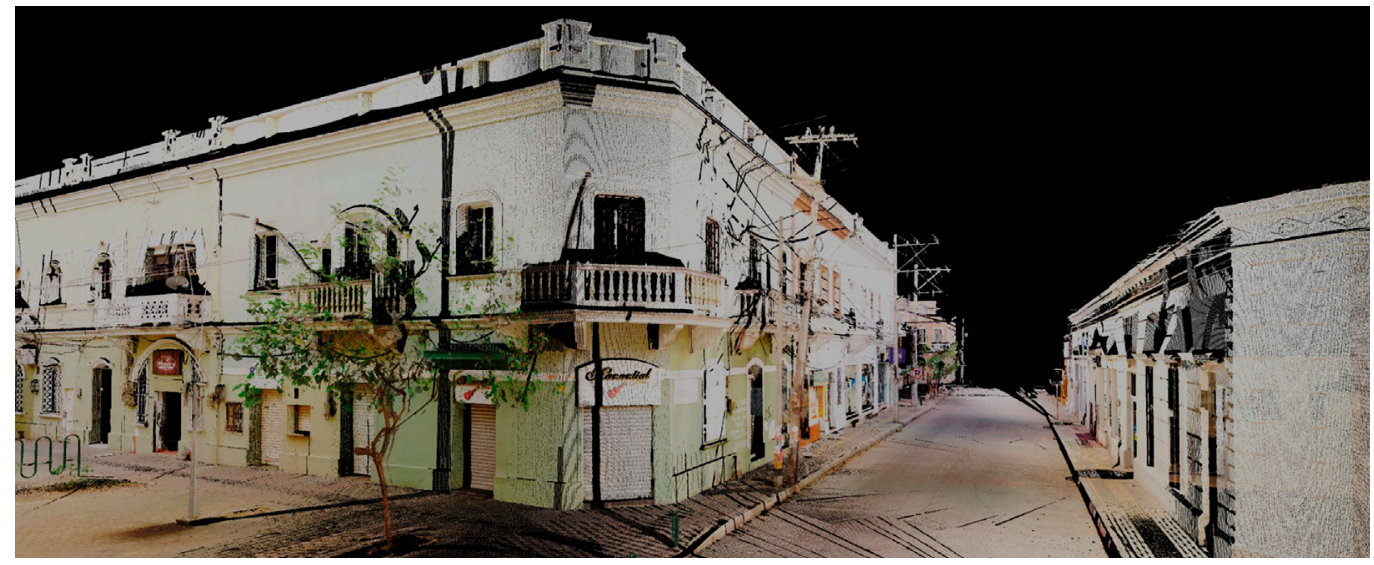




\section{Introduction}

Cultural heritage can be defined as the persistent identity of a city and its inhabitants. It is a discipline in continuous transformation that creates awareness and strengthens the pride of citizens in their local history [Hosagrahar 20 16]. Cultural resources in cities create a sense of belonging and identity among local communities by fostering strong social promotion, inclusion and equity. Furthermore, they promote the sustainable development of the city, attract local tourism, generate employment and improve living conditions. In this way, the promotion of cultural resources becomes a key element in consolidating an inclusive city. The enhancement of the architectural heritage is thus a duty for our communities, a mean of preservation that will make it possible to perpetuate local traditions with the aim of passing them on to the future generations [Maggi $20 \mathrm{II}$ ]. This research underlines the close relationship between documentation, interpretation and graphic representation of cultural heritage and its preservation over time.

Seeking to encourage heritage sustainability, an innovative research experience has been established, based on architectural surveys, as a fundamental tool for carrying out heritage conservation interventions [Contell 2008].

The context of this investigation is the city of Montería, currently known as the "Perla del Sinú" [Garcés González 1998], located in the northwest of the Colombian Caribbean coast (fig. I). A city with a great history, architectural legacies and customs rooted in the Sinú River; on the banks of the river, the first avenue offers a space for cultural exchange and gives rise to the largest linear park in Latin America, a space that has inspired poets, painters and artists all over the region [Exbrayat 197/]. It is necessary to recognize and preserve the identity of the city, whose characteristics have been shaped by its citizens.

The city acquired greater importance only in the middle of the 20th century with a notorious growth of the city as a result of its strategic geographical position that favored trade, and in this way, immigration [Castro 2003]. This commercial influence did not just consisted

Fig. I. Double illustration (n) Law of the Indies, on the left the Santa Marta Foundation (1551), on Carlos (1763). El Carbe Carlos (1763). El Caribe Colombiano, 2017.
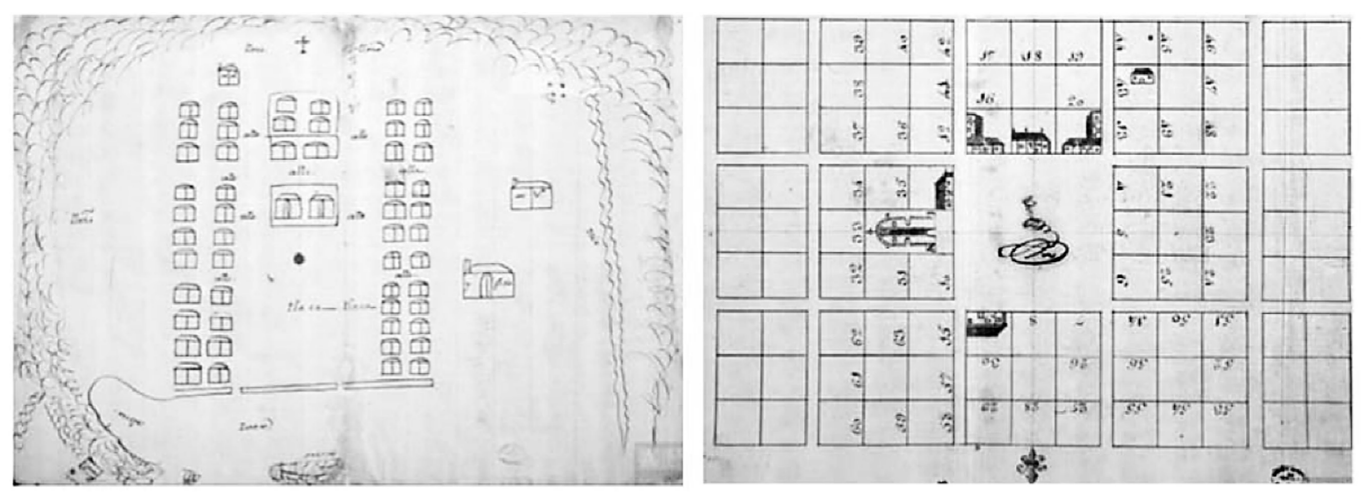

in the exchange of merchandise, but also of the artistic-architectural ideals; an example of this is this "Italian" house, whose value is mainly due to its style and the history surrounding its construction, therefore it comes the current need for research and preservation.

The Ferrari's house is probably a more unique than rare case of Liberty architecture in Montería and perhaps in the whole Colombian Caribbean [Bell Lemus 20 17]. This historical architecture is a central point of the cultural memory of the city. Due to the lack of bibliographic information or graphic documentation of the object of study, it has been necessary to resort to the only type of documentation available: old photographies.

The object of study, significant for its European imprint in a traditional native context, is identified within the "bienes culturales y arquitectonicos de la ciudad" [PEMP 20I9] and recognized as Liberty [Leserri 20I8], an Art Nouveau style with Italian influence, which 
aroused great interest in society for the purity of its construction and the peculiarity of the said cultural-architectural exchange.

However, the House is still not exploited as part of the city's heritage and therefore a specific study does not exist yet. There is no tangible documentation that allows us to study directly the origin and evolution that the house has suffered since its construction in 1935. The scarce documentation that can be recovered comes from the oral tradition of some historians of the city. There are photographic archives and books about the history of the city of Montería [Castro 2003], which explain the situation back then in relation to the trade, the transport, the economy and the social justification connected to the foreigners arrival to the city.

Using as a basis a documentary research that gathered the elements obtained from the oral tradition and the analysis of old documents, photographs and designs (fig. 2), it became possible to rescue the preexistences of the original composition. It is easy to verify the preservation over time of most of the constituent elements of the facade. As a strategy to reach an integrated awareness of the object of study, a methodology of documentation and graphic representation, which will constitute a fundamental basis to study the history and its changes over time, was implemented. A survey was carried out with the aim of exploring the particularities of the architecture, freeing it from the contemporary transformations and trying to obtain the image of the house in its original state.

The first stage of the research consisted of carrying out an analytical and visual tour of the architecture, history and style through a collection of old images of the city. The study, then, focused on the facade, being this the only accessible element for the analysis.

Fig. 2. Images of the "Italian" house from the Avenida primera in the 's. Unknown author, digitized by the Luis Angel Arango Library.
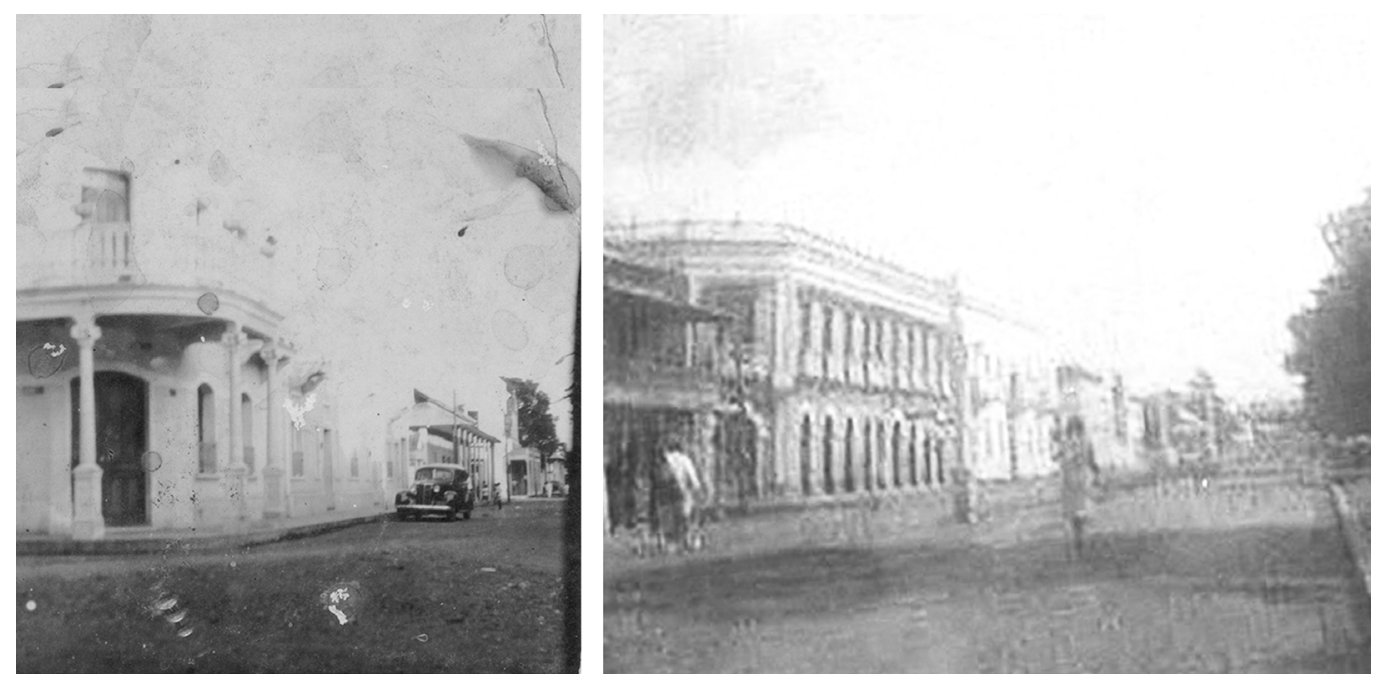

\section{Methods}

Although it is still common to use traditional resources for heritage documentation, such as photography or freehand drawing, thanks to their accessibility and low cost, today it is preferable to employ digital technologies, which are way more accurate but also imply an increase in the quantity and quality of captured data (fig. 3).

These new digital opportunities allow the researcher to experiment with different methods of communicating information through social networks and multimedia devices, thus reaching the user in a better and easier way, whilst leaving a greater social impact. 
Fig. 3. Diagram of the methodological procedure of the present project.

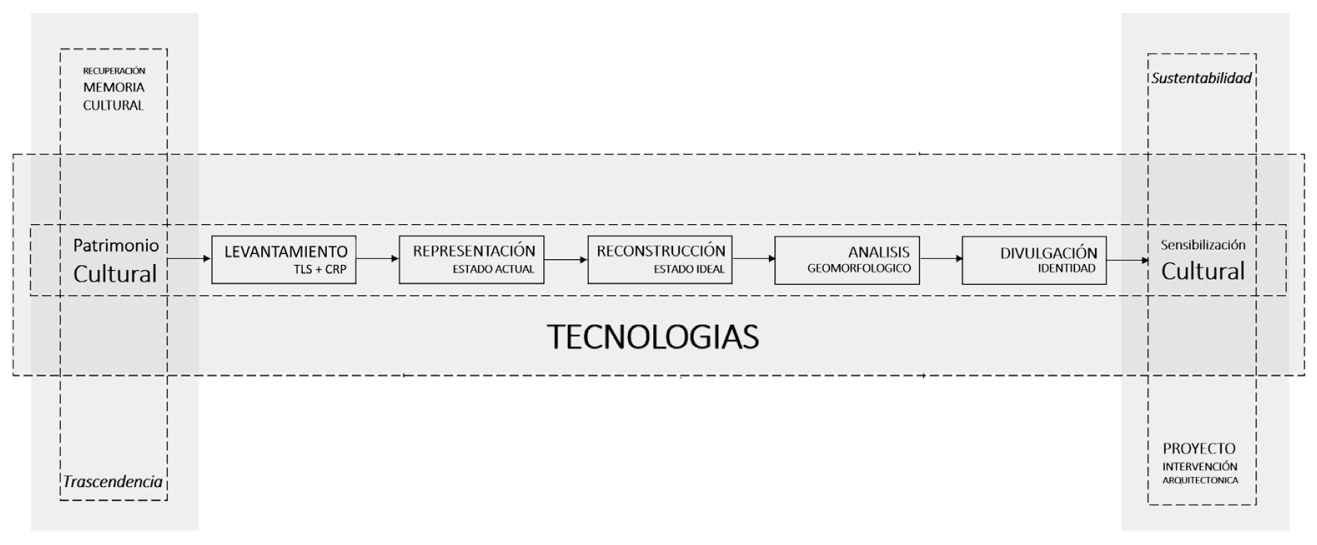

The data were captured and processed with the purpose of creating a documentation for their knowledge and management. The integration of the information into complex 3D models, implemented through interoperable platforms, becomes in this way an analysis tool for the management and monitoring process, and therefore for the conservation of the cultural heritage.

In the field of the digital graphic, the objective is to recover all the characteristic values of the object of study such as geometry, dimension and material among others; in order to later interpret them, and then interpret them, using the documentation obtained and analysing the possible transformations of the architecture over time [Florio 20l4].

Thanks to a multidisciplinary approach, with the contribution of different sectors such as history of architecture, graphic engineering and architectural restoration, it was proposed a research project based on the master thesis degree of Wendy Mejía Cabezas in 20 I9, it was possible to develop an optimized methodology to achieve the required objectives and to document and monitor the state of the art of historical-architectural assets, as a basis for a scientific interpretation of it.

The first phase of the research involved the collection of data and a significant iconographic and photographic analysis of the object of study. Afterwards, three data acquisition campaigns were carried out, using traditional and digital architectural survey techniques. Each object of study, in terms of monument, building, or decorative element, has unique characteristics and a peculiar state of preservation, hence the necessity to define the specific techniques used for each project, based on these singularities (Docci, 2003). Digital surveying techniques with active (TLS) and passive (CRP) sensor have been used.

TLS - Terrestrial Laser Scanning

A FARO M70 laser scanner from the Bari Polytechnic was used for indoor and outdoor applications requiring scans of up to 70 metres and an accuracy of $+/-1 \mathrm{~mm}$. With an acquisition speed of almost I.000.000 points per second. The acquisition campaign, carried out by Arch. Gabriele Rossi, has planned five stations (fig. 4) to guarantee the correct capture of the object of study. During the campaign, unforeseen events, such as the constant movement of people and vehicles, affected the acquisition of information globally. With the data provided by the scanner (in a .fls format) a point cloud of 119.861 .681 points was later created within the proprietary software Scene 2019.2.

CRP - Close Range Photogrammetry

A total of I 25 photos (fig. 4) were collected with a Nikon D3500 24,2MP kit I8-55mm, which is characterized by producing high quality images (.tiff), color and illumination. Only 99 photos were considered valid, after suppressing those that were out of focus, repeated and whose information had been altered by various elements of the outside environment. They were used to produce a 3D textured point cloud model within the software Agisoft Metashape 1.5. I. One of the main steps was to create a dense point cloud with 33.791.767 
points, which was later meshed into a polygonal surface of 2.252 .783 triangles, to get to the final application of the 4.096 pixels texture. To obtain accurate geospatial data, the photogrammetric results were matched with the georeferenced data acquired with TLS.

Terrestrial Laser Scanning + Close Range Photogrammetry

Using the data acquired by laser scanning and photogrammetry in the same reference system, the TLS point cloud was imported into Agisoft and a polygon mesh of 7.696 .809 triangles was generated. The texture was projected with the information from the photos, obtaining in this way, an integrated and more defined result. The orthophotos, one of each façade, were created with a resolution of $10.655 \times 3.919$ pixels, to be exported for a subsequent vectorization in a CAD environment. First of all, we obtained a high detailed representation of the state of art of the façades; on the other side, it was carried out a vectorization of the ideal original state of the façades, using as a scientific basis the orthophotos and interpreting the information gathered from the documentation compiled previously.

After a strategic cleaning of the point clouds, it was possible to obtain a clear visualization including the information referring to the material, the color and the geometry, so to realize the final orthophotographs of the facades and then be able to represent, by means of

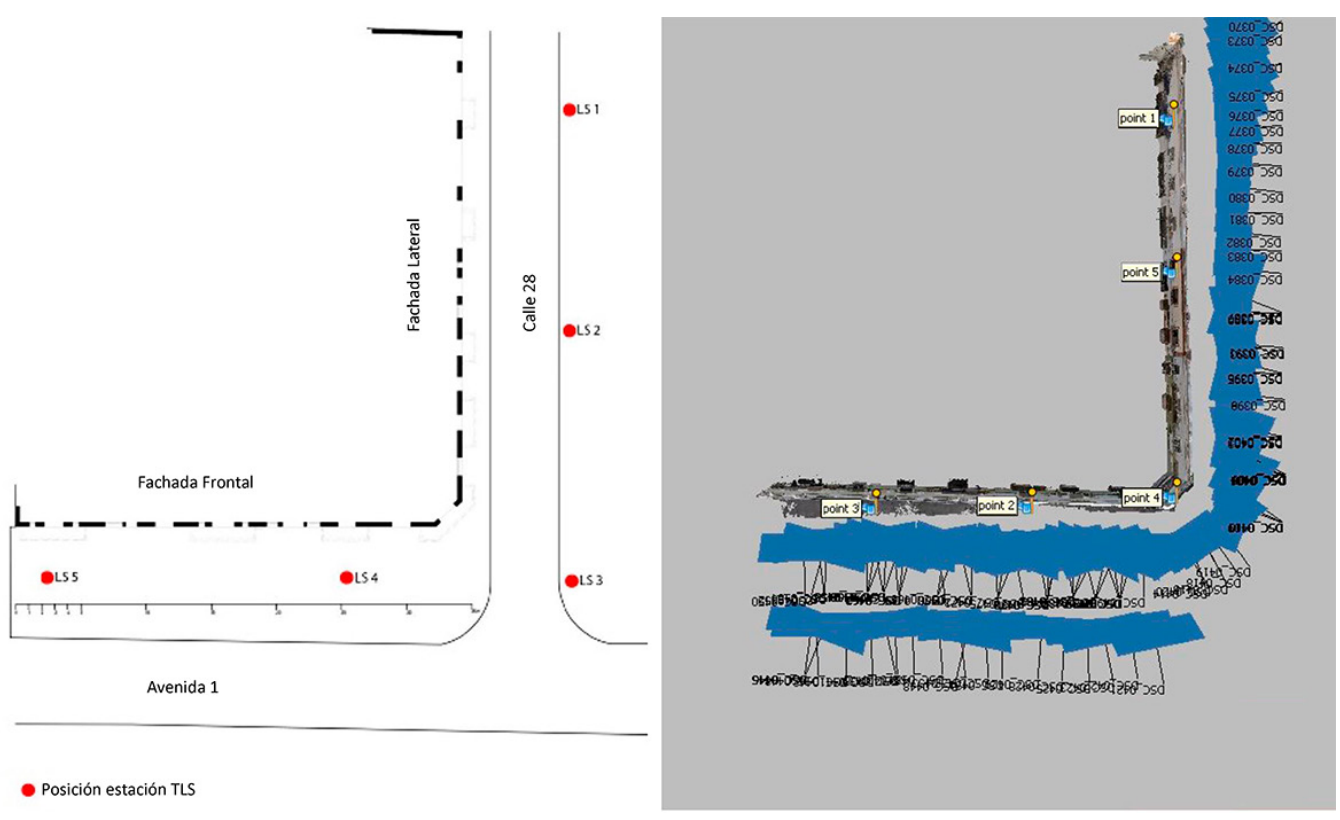

vector graphic code, their current and ideal state. The aim was to document and communicate the historical background of the house and help building a shared cultural memory. The results were technical drawing at the appropriate architectural scale, suitable to plan any further intervention on the façades of the Ferrari House. The last phase regarded the geomorphological analysis of the façade and the construction of a three-dimensional model of the current and the ideal state, loaded with historical components that will serve as the basis for future possible interventions.

\section{Results}

The potential of a three-dimensional model (fig. 5) is well-known in terms of analysis and interpretation, based not only on the digital data collected, but also on previous studies, observations and comparisons; so we can conclude that this approach is valid for scientific reconstructions. 
Fig. 5. A perspective of the polygonal model of the case study.

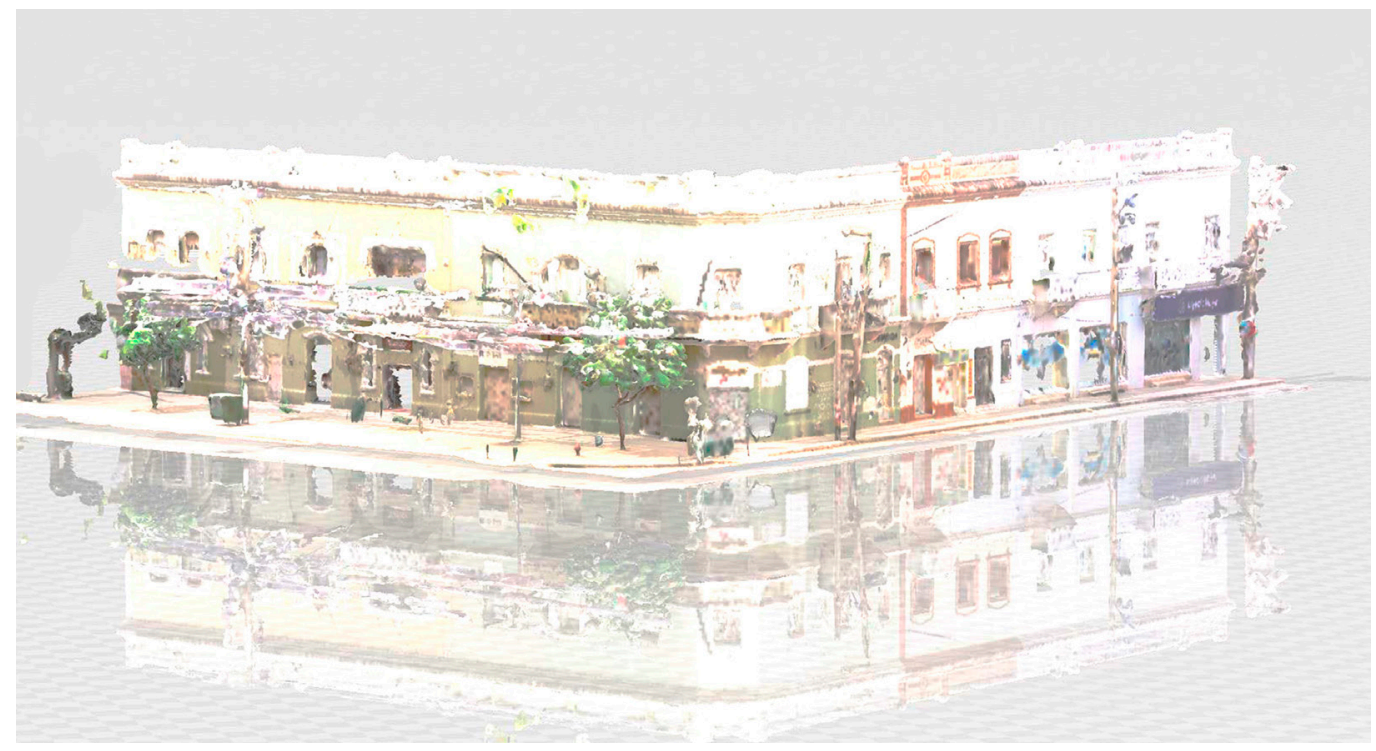

It was possible to obtain a visualization with information referring to the material, the color and the geometry, for the subsequent development of the 3D modelling [Piquer Cases 20 I5]. An intuitive and flexible software was used for the modeling, where the CAD vectorized drawing were imported. The polygonal surface helped to verify the perimeter of the external walls, the heights of the detail elements, such as the correct position of the doors, windows and all the external elements.

The opportunities offered by the integration of this modern digital techniques, such as photogrammetry with active laser scanner systems, allow to obtain new products with an improved accuracy of the metric data [Barba 2019]. This integration allows the virtual reconstruction of sites of artistic interest to faithfully document the reality. At the same time, it provides a tool to interpret visually the dynamics of the transformation of architectural objects through time.

In particular, the object of study is a building with a historical background not only because of the context in which it is built, but also because it belongs to an architectural style still not rooted into the contemporary buildings, with a strong Italian influence, designed by Italian engineers and built by Italian builders for an Italian family. The survey provided graphic material which, once combined with the research carried out, in terms of the acquisition of graphic and written documents and the analysis of the immediate context, made it possible to implement a hypothetical reconstruction of the original state of the object of study (figs. 6,7 ), with the intention to contribute to the social awareness of the importance of the enhancement of heritage, not only in Montería, but hopefully in different contexts too.

\section{Conclusions}

The façades of the Ferrari's family house are graphically documented. The documentation has been drawn up, for the first time, with scientific rigor and accompanied by in-depth documentary research that makes it possible to establish a graphic reconstruction of their original state. The architectural importance of the case study as cultural memory of the city of Montería, was revealed and so the stylistic and formal alterations of the facades. From these first outputs, is possible to see an increased social interest in the search for historical background of the object of study and its context. Therefore, the graphic representation of heritage becomes a first step towards its enhancement and for it to be considered a faithful reflection of the cultural identity and the historical memory of an inhabited territory. 




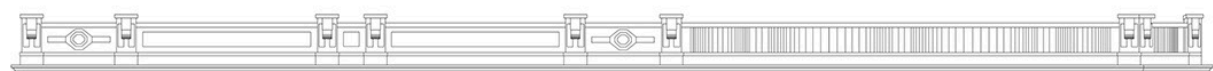

Fig. 6. Front facade: point cloud (TLS+CRP), geo-

referenced orthophoto,

current and ideal state

vectorization.

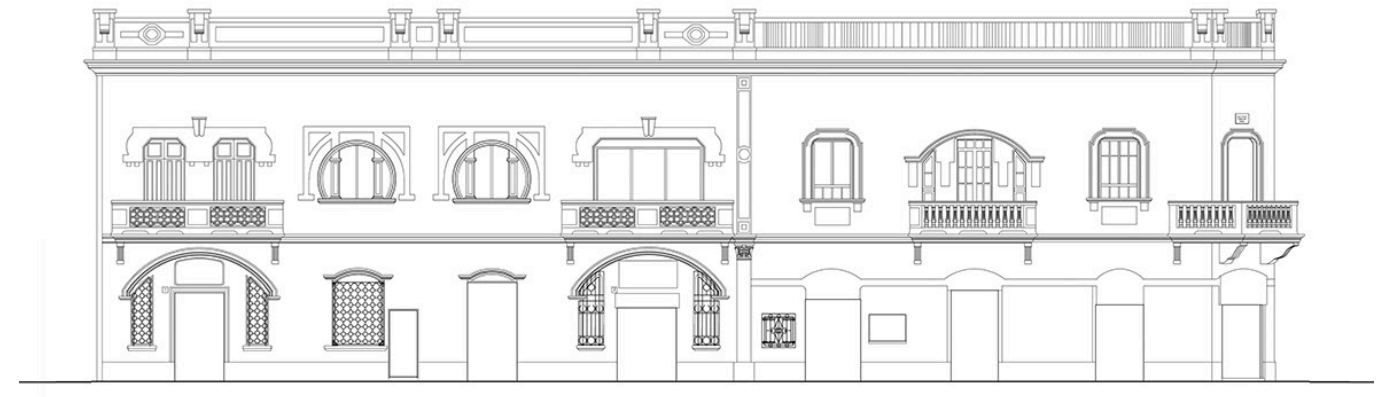

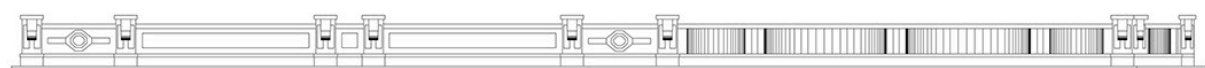
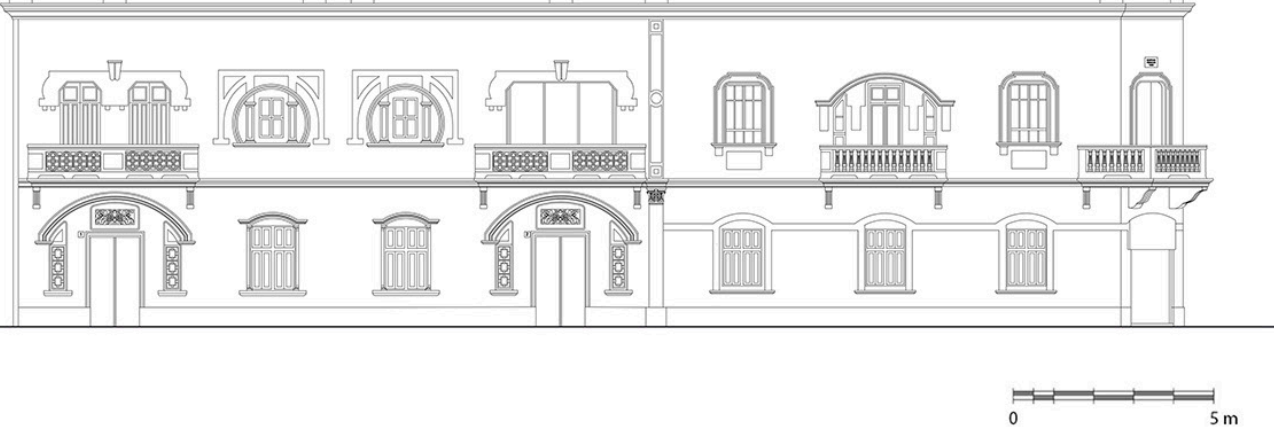

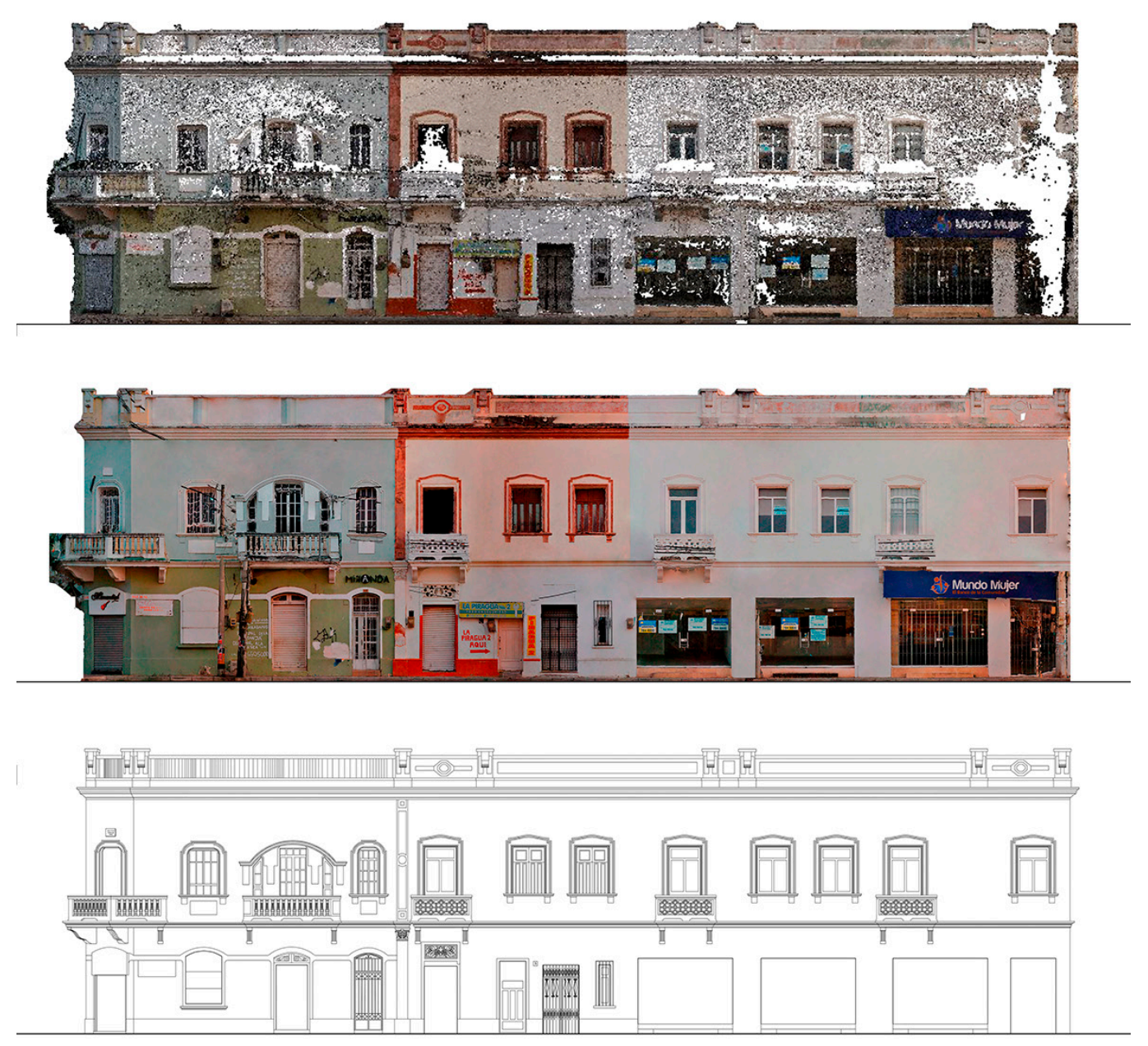

Fig. 7. Side facade: point

cloud (TLS+CRP), geo-

referenced or thophoto

current and ideal state

vectorization

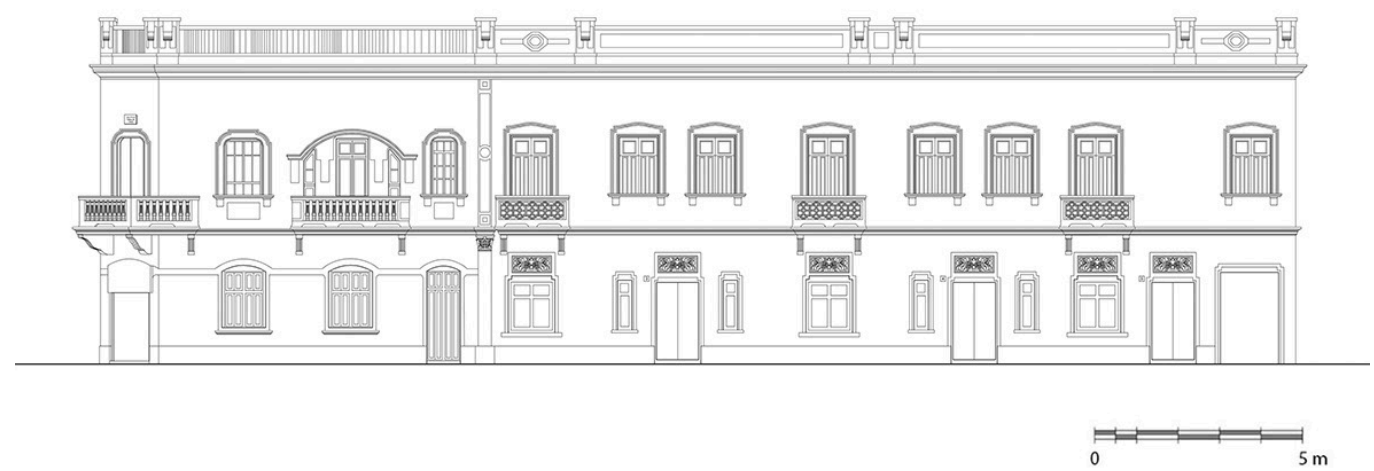


The methodology, based on multisensory surveys, iconographic documents, descriptions and historical background, made it possible to create a virtual model from which one can gather information on the architectural object and that, once put into its context, will lead to the strengthening of the urban memory [Rossi 2003]. The virtual reconstruction of a building not only helps to understand its totality, but also creates awareness of the dimension of heritage and becomes a powerful tool for dissemination, leading an even bigger audience towards a cultural promotion [Barba 20 I2].

The unpublished documentation obtained in this project will constitute a scientific basis to develop projects of an eventual renovation or restoration of the building, guaranteeing a saving of time and an accurate preview of the final representation (fig. 8).

The cultural interest that is developing in the city of Montería according to heritage requires a strengthening of the cultural debate to increase the political attention of public and private administrators.

As future developments, we will continue to research and collect information on the architectural heritage in Colombia. The Academy and the research should bring a specific interest towards the understanding of cultural heritage in the hope of developing a formative growth towards the culture of restoration.

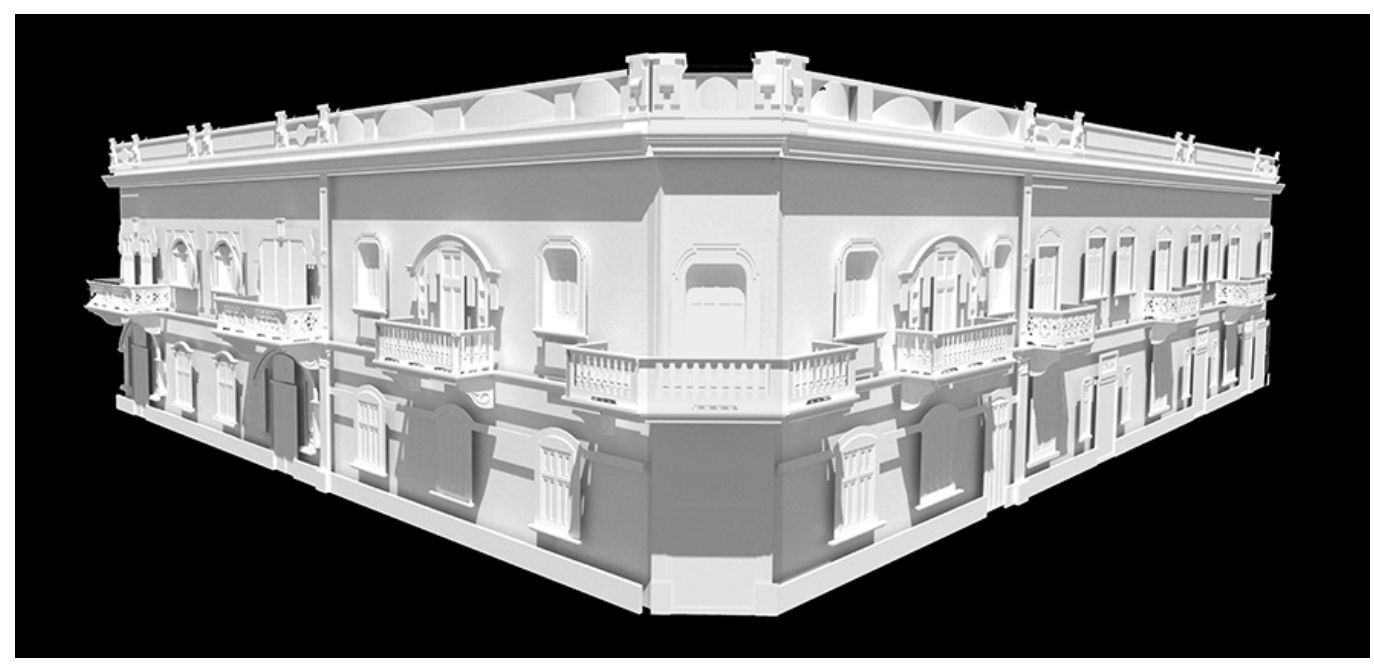

\section{References}

Barba Salvatore, De Feo Emanuela, D'Auria Saverio, Guerriero Luigi (20 I 2). Survey and virtual restoration:The Castle of Magacela, Spain. I 8th International Conference on Virtual Systems and Multimedia, Milan: IEEE, pp. 64 I-644.

Barba Salvatore, Barba Salvatore, di Filippo Andrea, Limongiello Marco, Messina Barbara (2019). Integration of active sensors for geometric analysis of the chapel of the Holy Shroud. In ISPRS - International Archives of the Photogrammetry, Remote Sensing and Spatial Information Sciences, Vol. XLII-2MI5.

Bell Lemus Carlos (2017). El Caribe Colombiano, Guía de Arquitectura y Pasaje. Sevilla: Barranquilla, pp. I7I.

Castro Jaime (2003). Historia extensa de Montería. Montería: Editorial ediciones Paloma.

Contell Marina (2008). El Monasterio De La Murta. El Levantamiento Arquitectónico como fase preliminar de estudio. In Revista de EGA, 13, pp. I28-133.

Docci Mario, Maestri Diego (2003). Manuale di rilevamento architettonico e urbano. Editorial Laterza. Roma-Bari.

Exbrayat Jaime (197|). Historia de Montería. Montería, Colombia: Domus Libri.

Florio Riccardo, Della Corte Teresa, Frajese D'Amato Carmela (20I4). Materia e forma dell'architettura dimenticata. ॥ patrimonio rupestre dell'area metropolitana di Napoli: il caso dell'Eremo di S. Maria di Pietraspaccata Mara. In Giandebiaggi Paolo (a cura di). Survey \& International Experience. atti del $36^{\circ}$ Convegno Internazionale dei Docenti della Rappresentazione. Parma I 8-20 settembre 20 |4. Roma: Gangemi Editore, pp. 297-305.

Garcés González José Luis (1998). Crónicas para intentar una historia. Montería, Colombia: Crónicas. 
Hosagrahar Jyoti, Duxbury Nancy, Pascual Jordi (2016). Why must culture be at the heart of sustainable urban development? Agenda 21 for culture - Committee on culture of United Cities and Local Governments.

Leserri Massimo, Guerrero Hernandez Maria (20I8). El Levantamiento como instrumento para el conocimiento del patrimonio arquitectónico. El caso estudio de la Ronda del Sinú de Montería. Campos, Umbrales y Poéticas del Dibujo. VII Congreso Internacional y XV Congreso Nacional de Profesores de Expresión gráfica en Ingeniería, Arquitectura y carreras afines. La Plata, Argentina.

Maggi Diana (20l I ). Patrimonio arquitectónico y urbano. Universidad Nacional de la Plata, Facultad de arquitectura y urbanismo. La Plata, Argentina: Unirio Editora.

Plan Especial de Manejo y Protección (PEMP) (2019). Centro Histórico de la ciudad de Montería, Colombia.

Piquer Cases Juan Carlos, Capilla Tamborero Esther, Molina-Siles Pedro (2015). La Reconstrucción Virtual del patrimonio arquitectónico y su aplicación metodológica. In Revista de EGA, 25, pp. 258-267.

Rossi Gabriele (2003). Piazza dei Mercadanti a Lecce, Indagini grafico-visuali sulle trasformazioni urbanistiche di Piazza Sant' Oronzo. Lecce: Edizioni Del Grifo.

\section{Authors}

Carla Ferreyra, Universidad de Salerno, cferreyra@unisa.it

Wendy Mejía Cabezas, Universidad Pontificia Bolivariana de Montería,wendy.mejiac@upb.edu.co.

Massimo Leserri, Universidad de Salerno, mleserri@unisa.it

To cite this chapter. Ferreyra Carla, Mejìa Cabezas Wendy, Leserri Massimo (2020). Levantamiento integrado para la documentación de arquitecturas históricas con influencia italiana en Colombia/Integrated surveying techniques for the documentation of historical architectures with Italian influence in Colombia. In Arena A., Arena M., Brandolino R.G., Colistra D., Ginex G., Mediati D., Nucifora S., Raffa P. (a cura di). Connettere. Un disegno per annodare e tessere. Atti del $42^{\circ}$ Convegno Internazionale dei Docenti delle Discipline della Rappresentazione/Connecting. Drawing for weaving relationships. Proceedings of the 42th International Conference of Representation Disciplines Teachers. Milano: FrancoAngeli, pp. 2162-2 I I . 